\title{
PENGETAHUAN, PERSEPSI DAN PERILAKU MAHASISWA DALAM PEMBELIAN NADA SAMBUNG
}

\author{
Rheza Ardiansyah ${ }^{1}$, Moh. Djemdjem Djamaludin $^{\left.{ }^{*}\right)}$, Tin Herawati ${ }^{1}$ \\ ${ }^{1}$ Departemen IImu Keluarga dan Konsumen, Fakultas Ekologi Manusia, Institut Pertanian Bogor, \\ Bogor 16680, Indonesia \\ ${ }^{*}$ E-mail: md_djamaludin@yahoo.co.id
}

\begin{abstract}
Abstrak
Tujuan dari penelitian ini adalah untuk menganalisis pengetahuan, persepsi, dan perilaku mahasiswa dalam pembelian nada sambung. Penelitian dengan desain cross sectional study dilaksanakan di Institut Pertanian Bogor. Jumlah mahasiswa dalam penelitian ini adalah 36 orang mahasiswa tingkat pertama yang mengaktifkan nada sambung pada saat survei pengguna nada sambung dilakukan. Data dikumpulkan melalui pengisian kuesioner penelitian. Data yang telah dikumpulkan dianalisis secara deskriptif dan regresi linear berganda. Hasil penelitian menunjukkan bahwa tingkat pengetahuan mahasiswa berada pada kategori tertinggi. Sementara itu, persepsi terhadap nada sambung berada pada tingkat kurang setuju. Mahasiswa memiliki perilaku pembelian nada sambung pada kategori sedang. Analisis regresi menunjukkan bahwa perilaku pembelian nada sambung mahasiswa dipengaruhi oleh persepsinya terhadap nada sambung $(p<0,01)$.
\end{abstract}

Kata kunci: nada sambung, pembelian, pengetahuan, perilaku, persepsi

\section{Knowledge, Perception, and Behavior of College Student in Ring Back Tone Purchasing}

\begin{abstract}
The aim of this research was to analyze the knowledge, perception, and ring back tone's purchasing behavior of college students. The research used cross-sectional design and conducted in Bogor Agricultural University. The amount of college students in this study was 36 of the first grade who activated ring back tone at the time when survey was held. Data were collected through filling in the questionnaire. The data were analyzed by descriptive statistic and multiple linear regression. Result showed that college student's knowledge level about ring back tone was in high stage. Meanwhile, perception toward ring back tone was in a less agree level. College students had ring back tone's purchasing behavior in moderate category. Regression analysis showed that ring back tone's purchasing behavior of College students was influenced by their perception $(p<0,01)$.
\end{abstract}

Keywords: behavior, knowledge, perception, purchasing, ring back tone

\section{PENDAHULUAN}

Pembajakan terhadap karya musik yang merugikan banyak pihak, hingga saat ini belum secara total diberantas. Menurut Asosiasi Industri Rekaman Indonesia (ASIRI), total penjualan musik legal dalam bentuk CD, kaset, dan VCD pada tahun 2007 hanya mencapai angka 19,4 juta keping, menurun sekitar 4,3 juta keping dari 2006 yang sebesar 23,7 juta. Sementara itu ASIRI juga merilis laporan bahwa total penjualan rekaman fisik tahun 2006 mengalami penurunan 21 persen jika dibandingkan dengan tahun 2005. Total penjualan unit kaset, CD, dan VCD tahun 2006 tercatat sebesar 23.736.355 keping di seluruh Indonesia. Jika di tahun 1996 ASIRI mencatat 20 juta keping album bajakan beredar, maka dua belas tahun kemudian yaitu pada tahun
2008 jumlahnya mencapai 550 juta keping (Putranto, 2010). Laporan ASIRI juga mencatat bahwa sepanjang tahun 2006 negara mengalami kerugian lebih dari 1,122 triliun rupiah yang seharusnya diperoleh dari penerimaan pajak. Pada tahun 2009, kerugian negara akibat berbagai kasus pelanggaran hak cipta di Indonesia mencapai 3 triliun rupiah (Putranto, 2009).

Kemunculan Ring Back Tone (RBT) atau nada sambung seakan menjadi titik terang peningkatan nilai apresiasi masyarakat terhadap karya musik. Nada sambung adalah nada pengganti dari nada standar yang digunakan sebagai tanda bahwa proses pemanggilan sedang dalam kondisi menunggu jawaban dari nomor yang dipanggil. Seluruh lagu yang dijadikan nada sambung tersimpan 
dalam server milik operator seluler yang mustahil ditembus oleh pembajak.

Besarnya pangsa pasar produk nada
sambung sebagai bagian dari jasa telekomunikasi terkadang dimanfaatkan oleh beberapa produsen untuk berbuat curang. Pengaduan tentang jasa telekomunikasi menduduki ranking pertama pengaduan yang diterima Yayasan Lembaga Konsumen Indonesia (YLKI). Laporan YLKI pada tahun 2010, ada 590 pengaduan konsumen, di mana 101-nya adalah pengaduan jasa telekomunikasi (YLKI, 2011).

Ketidakpuasan yang dialami konsumen adalah salah satu risiko yang mungkin dihadapi akibat perilaku pembeliannya. Perilaku pembelian nada sambung adalah akhir dari proses pengambilan keputusan untuk mengonsumsi produk itu. Menurut Sumarwan (2004), pengetahuan konsumen akan mempengaruhi keputusan pembelian. Selain pengetahuan, persepsi konsumen juga merupakan komponen lain yang dilalui dalam proses pembelian suatu produk. Sumarwan (2004) menyatakan bahwa persepsi konsumen sangat penting untuk diteliti dan dimengerti oleh pemasar atau produsen karena konsumen sering memutuskan membeli suatu produk berdasarkan persepsinya terhadap produk tersebut.

Hasil penelitian Fatmasari (2010) terkait persepsi konsumen terhadap layanan Ring Back Tone menunjukkan bahwa ada beberapa alasan konsumen untuk menggunakan nada sambung yaitu agar penelepon tidak merasa bosan, tidak merasa ketinggalan zaman, hanya iseng, untuk mengungkapkan isi hati, dan mengikuti konsumen lain. Hasil penelitian juga menunjukkan bahwa enam dari sepuluh konsumen tergolong konsumen aktif dan empat konsumen tergolong konsumen pasif. Konsumen aktif mendapatkan informasi dari internet, sedangkan konsumen pasif memperoleh informasi dari pamflet dan pesan singkat (SMS) yang dikirim oleh provider.

Penelitian ini dilakukan untuk menganalisis faktor eksternal, faktor internal, pengetahuan, persepsi, dan perilaku mahasiswa dalam pembelian nada sambung. Penelitian ini juga bertujuan untuk menganalisis pengaruh faktor eksternal (kelompok acuan), faktor internal (usia dan jenis kelamin), pengetahuan, dan persepsi mahasiswa terhadap perilaku pembelian nada sambung. Berdasarkan tujuan, penelitian ini menduga faktor eksternal, faktor internal, pengetahuan, dan persepsi berpengaruh terhadap perilaku pembelian nada sambung pada mahasiswa.

\section{METODE}

Disain yang digunakan dalam penelitian ini adalah cross sectional study yang dilakukan di Institut Pertanian Bogor (IPB). Pengambilan data dilakukan pada bulan Maret 2011 sampai dengan bulan Juli 2011. Mahasiswa yang terlibat dalam penelitian ini merupakan mahasiswa Tingkat Persiapan Bersama (TPB) IPB yang pada saat dilakukan survei sedang mengaktifkan nada sambung. Mahasiswa penelitian dipilih secara purposive. Penelitian diawali dengan survei pendahuluan untuk mengetahui jumlah serta identitas mahasiswa TPB yang menggunakan nada sambung. Hasil survei menunjukkan bahwa ada 36 mahasiswa yang dapat diikutsertakan dalam penelitian ini.

Data yang dikumpulkan berupa data primer yang diperoleh melalui pengisian kuesioner penelitian. Data primer meliputi faktor eksternal (karakteristik keluarga, kelompok acuan, dan sumber informasi), faktor internal (karakteristik mahasiswa), pengetahuan, persepsi, dan perilaku dalam pembelian nada sambung.

Pengetahuan diukur menggunakan 16 pernyataan dengan pilihan jawaban terdiri atas benar dan salah. Jawaban benar diberi bobot satu dan jawaban salah diberi bobot nol. Selanjutnya, skor yang diperoleh dijumlahkan dan dikategorikan menjadi tiga kategori, yaitu rendah $(0-33,3)$, sedang $(33,4-66,6)$, dan tinggi (66,7-100).

Persepsi diukur menggunakan 16 pernyataan dan pilihan jawabannya menggunakan skala Likert. Jawaban "sangat tidak setuju" diberi bobot satu, "tidak setuju" diberi bobot dua, "kurang setuju" diberi bobot tiga, "setuju" diberi bobot empat, dan "sangat setuju" diberi bobot lima. Persepsi terhadap nada sambung kemudian dibagi menjadi lima kategori, yaitu sangat tidak setuju $(16,0-28,8)$, tidak setuju $(28,9-41,6)$, kurang setuju $(41,7-$ $54,4)$, setuju $(54,5-67,2)$, dan sangat setuju $(67,3-80,0)$.

Perilaku pembelian nada sambung diukur dengan menggunakan 17 pernyataan yang menggunakan skala Likert sebagai pilihan jawabannya. Jawaban "tidak pernah" diberi bobot satu, "jarang" diberi bobot dua, "sering" diberi bobot tiga, dan "selalu" diberi bobot 
empat. Selanjutnya, skor yang diperoleh dijumlahkan dan dikategorikan menjadi empat kategori, yaitu tidak pernah (17-34), jarang (35-51), sering (52-68), dan selalu (69-85).

Analisis yang dilakukan terhadap data yang diperoleh adalah uji deskriptif dan uji regresi linier berganda. Uji deskriptif digunakan untuk menghitung nilai rata-rata, standar deviasi, dan tabulasi silang. Analisis regresi linear berganda digunakan untuk menganalisis pengaruh usia, uang saku, jenis kelamin, kelompok acuan, pengetahuan, dan persepsi konsumen terhadap perilaku pembelian nada sambung.

\section{HASIL}

\section{Karakteristik Mahasiswa}

Karakteristik mahasiswa yang diukur adalah jenis kelamin, usia, penyedia layanan ponsel, uang saku, dan daerah asal. Hasil penelitian menunjukkan bahwa tiga dari empat mahasiswa berjenis kelamin perempuan. Berdasarkan peng-golongan usia menurut Cobb (2001), tiga dari lima mahasiswa yang terlibat dalam penelitian ini berusia 19 tahun dan tergolong dalam usia remaja akhir (usia 1619 tahun).

Penyedia layanan ponsel dalam penelitian ini meliputi Esia, Indosat, Telkomsel, Tri, dan XL. Hasil penelitian menunjukkan bahwa persentase tertinggi mahasiswa $(47,2 \%)$ menulis Indosat sebagai penyedia layanan ponsel yang diaktifkan. Penyedia layanan ponsel yang diaktifkan pada urutan kedua adalah XL $(38,9 \%)$.

Jika dilihat dari jumlah uang saku, separuh mahasiswa memiliki uang saku antara Rp500.000,00 sampai dengan Rp750.000,00. Rata-rata uang saku yang dimiliki mahasiswa adalah Rp741.515,20 dengan standar deviasi sebesar Rp205.549,90. Sementara itu, jika dilihat dari daerah asal, satu dari empat mahasiswa yang terlibat dalam penelitian ini berasal dari Jawa Barat dan Jawa Timur. Sebaran mahasiswa berdasarkan karakteristiknya disajikan pada Tabel 1.

\section{Karakteristik Keluarga}

Karakteristik keluarga yang diukur meliputi besar keluarga, pekerjaan orang tua, dan pendapatan keluarga. Data yang diperoleh menunjukkan bahwa enam dari sepuluh keluarga mahasiswa tergolong dalam keluarga sedang dengan jumlah anggota keluarga 5-6 orang. Berdasarkan jenisnya, pekerjaan yang dilakukan ayah cukup bervariasi dengan persentase tertinggi sebagai Pegawai Negeri Sipil $(41,7 \%)$. Sementara itu, separuh mahasiswa memiliki ibu yang tidak bekerja atau bekerja sebagai ibu rumah tangga. Jika dilihat dari aspek pendapatan keluarga, data yang diperoleh juga menunjukkan bahwa persentase terbesar pendapatan keluarga mahasiswa (55,6\%) berada pada selang Rp600.000,00 sampai dengan Rp4.400.000,00. Rata-rata pendapatan yang dimiliki keluarga adalah Rp4.232.888,50 dengan standar deviasi sebesar Rp2.691.895,80. Sebaran mahasiswa berdasarkan karakteristik keluarga disajikan pada Tabel 2.

Tabel 1 Sebaran mahasiswa berdasarkan karakteristiknya

\begin{tabular}{|c|c|c|}
\hline Kategori & Jumlah & Persentase \\
\hline \multicolumn{3}{|l|}{ Jenis kelamin } \\
\hline Laki-laki & 9 & 25,0 \\
\hline Perempuan & 27 & 75,0 \\
\hline Total & 36 & 100,0 \\
\hline \multicolumn{3}{|l|}{ Usia (tahun) } \\
\hline 17 & 1 & 2,8 \\
\hline 18 & 13 & 36,1 \\
\hline 19 & 21 & 58,3 \\
\hline 20 & 1 & 2,8 \\
\hline Total & 36 & 100,0 \\
\hline $\begin{array}{l}\text { Rata-rata } \pm \text { Standar } \\
\text { deviasi }\end{array}$ & \multicolumn{2}{|c|}{$18,6 \pm 0,6$} \\
\hline \multicolumn{3}{|l|}{ Penyedia layanan ponsel } \\
\hline Esia & 1 & 2,8 \\
\hline Indosat & 17 & 47,2 \\
\hline Telkomsel & 2 & 5,6 \\
\hline Tri & 2 & 5,6 \\
\hline$X L$ & 14 & 38,9 \\
\hline Total & 36 & 100,0 \\
\hline \multicolumn{3}{|l|}{ Uang saku (rupiah) } \\
\hline $500.000-750.000$ & 19 & 52,8 \\
\hline $750.001-1.000 .000$ & 8 & 22,2 \\
\hline $1.000 .001-1.200 .000$ & 9 & 25,0 \\
\hline Total & 36 & 100,0 \\
\hline $\begin{array}{l}\text { Rata-rata } \pm \text { Standar } \\
\text { deviasi }\end{array}$ & \multicolumn{2}{|c|}{$741.515,2 \pm 205.549,9$} \\
\hline \multicolumn{3}{|l|}{ Daerah asal } \\
\hline Bali & 1 & 2,8 \\
\hline Banten & 5 & 13,9 \\
\hline Jawa Barat & 9 & 25,0 \\
\hline Jakarta & 5 & 13,9 \\
\hline Jawa Tengah & 3 & 8,3 \\
\hline Jawa Timur & 9 & 25,0 \\
\hline Sulawesi & 1 & 2,8 \\
\hline Sumatera & 3 & 8,3 \\
\hline Total & 36 & 100,0 \\
\hline
\end{tabular}


Tabel 2 Sebaran mahasiswa berdasarkan karakteristik keluarga

\begin{tabular}{|c|c|c|}
\hline Kategori & Jumlah & Persentase \\
\hline \multicolumn{3}{|l|}{ Besar keluarga } \\
\hline Keluarga kecil ( $\leq 4$ orang) & 12 & 33,3 \\
\hline $\begin{array}{l}\text { Keluarga sedang (5-6 } \\
\text { orang) }\end{array}$ & 22 & 61,1 \\
\hline $\begin{array}{l}\text { Keluarga besar }(\geq 7 \\
\text { orang) }\end{array}$ & 2 & 5,6 \\
\hline Total & 36 & 100,0 \\
\hline $\begin{array}{l}\text { Rata-rata } \pm \text { Standar } \\
\text { deviasi }\end{array}$ & \multicolumn{2}{|c|}{$4,9 \pm 1,0$} \\
\hline \multicolumn{3}{|l|}{ Pekerjaan Ayah } \\
\hline PNS & 15 & 41,7 \\
\hline Pegawai swasta & 5 & 13,9 \\
\hline TNI/Polri & 2 & 5,6 \\
\hline Wiraswasta & 10 & 27,8 \\
\hline Tidak bekerja & 2 & 5,6 \\
\hline Pensiunan & 2 & 5,6 \\
\hline Total & 36 & 100,0 \\
\hline \multicolumn{3}{|l|}{ Pekerjaan Ibu } \\
\hline PNS & 13 & 37,1 \\
\hline Pegawai swasta & 1 & 2,9 \\
\hline Wiraswasta & 2 & 5,7 \\
\hline Tidak bekerja & 18 & 51,4 \\
\hline Pensiunan & 1 & 2,9 \\
\hline Total & 36 & 100,0 \\
\hline \multicolumn{3}{|c|}{ Pendapatan keluarga mahasiswa per bulan (Rp) } \\
\hline $600,000-4,400,000$ & 20 & 55,6 \\
\hline $4,400,001-8,200,000$ & 13 & 36,1 \\
\hline $8,200,001-12,000,000$ & 3 & 8,3 \\
\hline Total & 36 & 100,0 \\
\hline $\begin{array}{l}\text { Rata-rata } \pm \text { Standar } \\
\text { deviasi }\end{array}$ & \multicolumn{2}{|c|}{$\begin{array}{c}4.232 .888,5 \pm \\
2.691 .895,8\end{array}$} \\
\hline Min - maks (Rp) & \multicolumn{2}{|c|}{$600.000-12.000 .000$} \\
\hline
\end{tabular}

\section{Pola Penggunaan Nada Sambung}

Aspek pola penggunaan nada sambung yang diukur dalam penelitian ini meliputi lama pengaktifan nada sambung, jumlah ponsel yang digunakan, sumber informasi, dan jenis nada sambung. Sebanyak 72,2 persen mahasiswa telah mengaktifkan nada sambung selama 1-20 bulan. Dua dari tiga mahasiswa yang terlibat dalam penelitian menggunakan satu ponsel dan masih mengaktifkan nada sambung.

Berdasarkan sumber informasi, satu dari tiga mahasiswa menerima informasi dari sumber publik berupa televisi. Sementara itu, berdasarkan jenis nada sambung, sebagian besar mahasiswa $(86,5 \%)$ mengaktifkan musik pop sebagai nada sambung mereka. Musik pop adalah jenis musik yang mudah ditemui dan biasanya menggunakan topik asmara sebagai topik sentral. Sebaran mahasiswa berdasarkan pola penggunaan nada sambung disajikan pada Tabel 3.
Tabel 3 Sebaran mahasiswa berdasarkan penggunaan nada sambung

\begin{tabular}{lrr}
\hline Kategori & Jumlah & Persentase \\
\hline Lama pengaktifan nada sambung & & \\
$1-20$ & 26 & 72,2 \\
$21-40$ & 5 & 13,9 \\
$41-60$ & 2 & 5,6 \\
$61-80$ & 3 & 8,3 \\
\hline Jumlah ponsel yang digunakan (unit) & \\
1 & 24 & 66,7 \\
2 & 12 & 33,3 \\
Total & 36 & 100,0 \\
\hline Sumber informasi & & \\
Sumber pribadi & 8 & 16,7 \\
Sumber komersial & 16 & 33,3 \\
Sumber public & 24 & 50,0 \\
\hline Jenis nada sambung & & \\
Musik rock & 2 & 5,4 \\
Musik pop & 32 & 86,5 \\
Rekaman percakapan & 1 & 2,7 \\
Musik RnB & 2 & 5,4 \\
\hline
\end{tabular}

Penelitian ini juga menganalisis fitur yang menjadi prioritas mahasiswa. Fitur yang menjadi prioritas pertama dan kedua untuk dibiayai paling banyak mahasiswa adalah SMS (52,8\% dan 47,2\%). Sebaran mahasiswa menurut urutan prioritas pengeluaran untuk penggunaan berbagai layanan ponsel disajikan pada Tabel 4.

\section{Kelompok Acuan}

Menurut Sumarwan (2004), kelompok acuan adalah seorang individu atau sekelompok orang yang secara nyata mempengaruhi perilaku seseorang. Kelompok acuan akan memberikan standar dan nilai yang akan mempengaruhi perilaku seseorang. Berdasarkan hasil, diperoleh informasi bahwa kebanyakan mahasiswa $(39,5 \%)$ menjadikan temannya sebagai kelompok acuan. Sebaran mahasiswa berdasarkan kelompok acuan dalam pengaktifan nada sambung disajikan pada Tabel 5.

Tabel 4 Sebaran mahasiswa menurut urutan prioritas pengeluaran untuk penggunaan berbagai layanan ponsel

\begin{tabular}{lrrrr}
\hline $\begin{array}{c}\text { Urutan } \\
\text { prioritas }\end{array}$ & \multicolumn{1}{c}{ SMS } & Telepon & Internet & $\begin{array}{c}\text { Nada } \\
\text { sambung }\end{array}$ \\
\hline Pertama & 52,8 & 36,1 & 11,1 & 0,0 \\
Kedua & 47,2 & 33,3 & 19,4 & 0,0 \\
Ketiga & 0,0 & 25,0 & 52,8 & 22,2 \\
Keempat & 0,0 & 5,6 & 16,7 & 77,8 \\
\hline Jumlah & 100,0 & 100,0 & 100,0 & 100,0 \\
\hline
\end{tabular}


Tabel 5 Sebaran mahasiswa menurut kelompok acuan dalam pengaktifan nada sambung

\begin{tabular}{lrr}
\hline \multicolumn{1}{c}{ Kelompok acuan } & Jumlah & Persentase \\
\hline Teman & 15 & 39,5 \\
Pacar & 3 & 7,9 \\
Tokoh idola & 4 & 10,5 \\
Promosi dari operator & 7 & 18,4 \\
Tidak memiliki kelompok & 9 & 23,7 \\
acuan &
\end{tabular}

\section{Pengetahuan Konsumen}

Peter dan Olson (1996) membagi pengetahuan konsumen menjadi dua jenis, yaitu pengetahuan umum tentang lingkungan dan perilaku mereka dan pengetahuan prosedural tentang cara melakukan sesuatu. Sumarwan (2004) juga menyatakan bahwa Engel, Blackwell dan Miniard (1995) membagi pengetahuan konsumen menjadi tiga macam, yaitu pengetahuan produk, pengetahuan pembelian dan pengetahuan pemakaian. Hasil penelitian menunjukkan bahwa lebih dari separuh mahasiswa $(55,6 \%)$ memiliki tingkat pengetahuan yang tinggi tentang nada sambung. Sebaran mahasiswa berdasarkan tingat pengetahuannya tentang nada sambung disajikan pada Tabel 6 . Tabel 6 juga memperlihatkan bahwa tidak ada mahasiswa yang memiliki tingkat pengetahuan pada kategori rendah.

\section{Persepsi Konsumen}

Sumarwan (2004) menyatakan bahwa konsumen seringkali memutuskan pembelian suatu produk berdasarkan persepsinya terhadap produk tersebut. Persepsi yang dimaksud dalam penelitian ini adalah pendapat mahasiswa tentang keberadaan nada sambung. Hasil penelitian menunjukkan bahwa lebih dari separuh mahasiswa (55,6\%) berpersepsi bahwa mereka merasa kurang setuju dengan keberadaan nada sambung. Sebaran mahasiswa berdasarkan tingat persepsinya tentang nada sambung disajikan pada Tabel 7 .

Tabel 6 Sebaran mahasiswa menurut tingkat pengetahuan tentang nada sambung

\begin{tabular}{lrr}
\hline \multicolumn{1}{c}{ Tingkat pengetahuan } & Jumlah & Persentase \\
\hline Rendah (skor 0-33,3) & 0 & 0,0 \\
Sedang (skor 33,4-66,6) & 16 & 44,4 \\
Tinggi (skor 66,7-100) & 20 & 55,6 \\
\hline Total & 36 & 100,0 \\
Min-maks & $43,8-87,5$ \\
Rata-rata \pm Standar deviasi & $66,3 \pm 10,4$ \\
\hline
\end{tabular}

Tabel 7 Sebaran mahasiswa menurut persepsi tentang nada sambung

\begin{tabular}{lrr}
\hline \multicolumn{1}{c}{ Persepsi mahasiswa } & Jumlah & Persentase \\
\hline $\begin{array}{l}\text { Sangat tidak setuju (skor } \\
\text { 16-28,8) }\end{array}$ & 0 & 0,0 \\
$\begin{array}{l}\text { Tidak setuju (skor 28,9- } \\
\text { 41,6) }\end{array}$ & 6 & 16,7 \\
$\begin{array}{l}\text { Kurang setuju (skor 41,7- } \\
\text { 54,4) }\end{array}$ & 20 & 55,6 \\
Setuju (skor 54,5-67,2) & 10 & 27,8 \\
Sangat setuju (skor 67,3- & 0 & 0,0 \\
80) & 36 & 100,0 \\
\hline Total & \multicolumn{2}{c}{$34-65$} \\
Min-Maks & \multicolumn{2}{c}{$49,9 \pm 7,8$} \\
$\begin{array}{l}\text { Rata-rata } \pm \text { Standar } \\
\text { deviasi }\end{array}$ & \multicolumn{2}{c}{} \\
\hline
\end{tabular}

\section{Perilaku Pembelian}

Sumarwan (2004) menyatakan bahwa saat konsumen telah memutuskan alternatif produk yang akan dipilihnya, maka ia akan melakukan pembelian. Pembelian meliputi keputusan konsumen mengenai apa yang dibeli, apakah membeli atau tidak, kapan membeli, dimana membeli, dan bagaimana cara membayarnya. Hasil penelitian menunjukkan bahwa hampir separuh mahasiswa $(47,2 \%)$ memiliki perilaku pembelian dalam kategori jarang (Tabel 8).

Pengaruh jenis kelamin, usia, uang saku, pengetahuan, dan persepsi mahasiswa terhadap perilaku pembelian nada sambung

Model yang disusun untuk menganalisis pengaruh jenis kelamin, usia, uang saku, pengetahuan, dan persepsi mahasiswa terhadap perilaku pembelian nada sambung memiliki koefisien determinasi (adjusted $R$ square) sebesar 0,231. Artinya, 23,1 persen varian perilaku pembelian nada sambung dapat dijelaskan oleh perubahan dalam variabelvariabel yang ada di dalam model. Sisanya yaitu sebesar 76,9 persen perilaku pembelian nada sambung dipengaruhi oleh variabel lain yang tidak diteliti dalam penelitian ini (Tabel 9).

Tabel 8 Sebaran mahasiswa menurut perilaku pembelian nada sambung

\begin{tabular}{lrr}
\hline \multicolumn{1}{c}{ Perilaku pembelian } & Jumlah & Persentase \\
\hline Tidak pernah (skor 17-34) & 12 & 33,3 \\
Jarang (skor 35-51) & 17 & 47,2 \\
Sering (skor 52-68) & 7 & 19,4 \\
Selalu (skor 69-85) & 0 & 0,0 \\
\hline Total & 36 & 100,0 \\
Min-Maks & \multicolumn{2}{c}{$23-63$} \\
Rata-rata \pm Standar & \multicolumn{2}{c}{$40,5 \pm 10,4$} \\
deviasi
\end{tabular}



Tabel 9 Pengaruh jenis kelamin, usia, uang saku, pengetahuan, dan persepsi mahasiswa terhadap nada sambung terhadap perilaku pembelian nada sambung

\begin{tabular}{lccc}
\hline \multicolumn{1}{c}{ Variabel bebas } & $\beta$ & $\mathrm{T}$ & Sig. \\
\hline Usia & $-0,088$ & $-0,562$ & 0,578 \\
Uang saku & $-0,055$ & $-0,354$ & 0,726 \\
Jenis kelamin & 0,324 & 1,991 & 0,056 \\
Kelompok acuan & 0,074 & 0,431 & 0,670 \\
$\begin{array}{l}\text { (1=teman; 0=bukan } \\
\text { teman) } \\
\text { Pengetahuan }\end{array}$ & 0,005 & 0,029 & 0,977 \\
Persepsi & 0,561 & 3,388 & $0,002^{*}$ \\
\hline $\mathrm{n}$ & \multicolumn{3}{c}{36} \\
$\mathrm{~F}$ & \multicolumn{3}{c}{$2,753(\mathrm{p}=0,030)$} \\
$\mathrm{R}^{2}$ & 0,363 \\
Adjusted $R$ Square & \multicolumn{3}{c}{0,231} \\
\hline Keterangan: * Nyata pada $\mathrm{p}<0,01$
\end{tabular}

Hasil analisis regresi yang disajikan pada Tabel 9 menunjukkan bahwa persepsi mahasiswa terhadap nada sambung berpengaruh signifikan positif terhadap perilaku pembelian nada sambung $(\beta=0,561, p<0,01)$. Hasil ini menunjukkan bahwa jika persepsi mahasiswa meningkat satu satuan maka perilaku pembelian nada sambung juga akan meningkat sebesar 0,561. Persepsi mahasiswa yang semakin baik pada nada sambung dapat meningkatkan perilaku mahasiswa untuk menggunakan nada sambung.

\section{PEMBAHASAN}

Tiga per empat jumlah mahasiswa penelitian ini berjenis kelamin perempuan. Sementara itu lebih dari separuh (58\%) mahasiswa berusia 19 tahun. Menurut Cobb (2001) usia tersebut termasuk ke dalam golongan remaja akhir. Solomon (1992) menyatakan jenis kelamin merupakan komponen penting dalam pembentukan konsep diri konsumen. Konsumen selalu menyesuaikan diri dengan produk yang dikonsumsinya agar sesuai dengan konsep budayanya tentang jenis kelamin. Hawkins et al. (2001) menyatakan bahwa usia seseorang akan menentukan media apa yang digunakan, tempat belanja yang dituju, bagaimana menggunakan produk, dan bagaimana konsumen merasakan dan berpikir tentang aktivitas pemasaran.

Kotler dan Armstrong (2008) mengidentifikasi lima segmen tahap kehidupan konsumen. Segmen pertama adalah pemuda yang meliputi konsumen yang berusia lebih muda dari 18 tahun. Segmen kedua adalah konsumen mulai dewasa yang memiliki rentang usia 18-35 tahun yang melewati berbagai pengalaman pertamanya, seperti kelulusan, kartu kredit pertama, mobil pertama, pinjaman pertama, pernikahan dan anak pertama. Segmen ketiga dihuni para konsumen yang berusia antara 35-50 tahun yang sedang berada dalam tahun pendapatan puncak mereka. Segmen akumulator adalah konsumen yang berusia 50-60 tahun. Mereka khawatir dengan tabungan pensiunnya dan melakukan investasi dengan bijak. Segmen terakhir adalah segmen lanjut usia. Konsumen ini ingin memaksimalkan pendapatan pensiunnya untuk mempertahankan gaya hidup yang ia inginkan. Hasil penelitian menunjukkan bahwa kebanyakan mahasiswa tergolong segmen kedua. Berdasarkan informasi di atas, konsumen dengan rentang usia ini akan bersikap hati-hati dengan pengeluarannya.

Hasil penelitian menunjukan bahwa sebagian besar mahasiswa penelitian berada pada interval uang saku terkecil, yaitu antara Rp500.000,00-Rp750.000,00. Pendapatan seorang konsumen adalah salah satu aspek yang digunakan untuk mengidentifikasi status sosial. Uang saku bagi mahasiswa bertindak sebagai salah satu pendapatan yang akan menentukan kelas sosialnya. Kotler dan Armstrong (2008) menyatakan bahwa kelas sosial berguna untuk mengidentifikasi kecenderungan pembelian konsumen, karena konsumen yang berada pada kelas sosial yang sama akan melakukan perilaku pembelian yang sama. Uang saku juga bisa digunakan untuk mengidentifikasi situasi ekonomi konsumen. Kotler dan Armstrong (2008) menyatakan bahwa situasi ekonomi seseorang akan mempengaruhi pilihan produk yang dibelinya.

Sebanyak 61,1 persen keluarga mahasiswa tergolong keluarga sedang yang jumlah anggota keluarganya 5-6 orang. Kotler dan Armstrong (2008) menyatakan bahwa anggota keluarga bisa sangat mempengaruhi perilaku pembelian. Dengan banyaknya jumlah anggota keluarga, maka makin banyak pula peluang seorang konsumen dipengaruhi anggota keluarga lainnya.

Berdasarkan hasil penelitian, lebih dari setengah mahasiswa (55,6\%) memiliki pendapatan keluarga antara Rp600.000,00Rp4.400.000,00 dengan pendapatan rata-rata Rp4.232.888,50. Kotler dan Armstrong (2008) menyatakan bahwa kelas sosial adalah pembagian masyarakat yang relatif permanen dan berjenjang yang anggotanya memiliki nilai, minat, dan perilaku yang sama. Schiffman dan Kanuk (1994) menyatakan bahwa kelas sosial 

dapat diidentifikasi menurut satu atau beberapa variabel demografis seperti pekerjaan, pendapatan, pendidikan, kekayaan dan variabel lain. Konsumen yang berada pada satu kelas sosial yang sama cenderung memperlihatkan perilaku pembelian yang sama. Dalam penelitian ini, kelas sosial diidentifikasi dari pekerjaan dan pendapatan. Sebaran pekerjaan orang tua menunjukkan bahwa jenis pekerjaan terbanyak ayah $(41,7 \%)$ adalah Pegawai Negeri Sipil (PNS). Sementara itu separuh mahasiswa memiliki ibu yang tidak bekerja atau menjalani profesi sebagai ibu rumah tangga.

Nada sambung merupakan salah satu produk musik, sehingga keterangan diatas sesuai dengan hasil penelitian yang menyatakan bahwa kebanyakan (58,3\%) mahasiswa yang merupakan konsumen nada sambung berusia 19 tahun. Schiffman dan Kanuk (1994) menyatakan bahwa fokus produk untuk konsumen yang berusia antara 18 hingga 29 tahun adalah musik, busana dan bahasa.

Menurut hasil penelitian, lebih dari setengah mahasiswa menggunakan satu ponsel, sementara mahasiswa lainnya menggunakan dua ponsel dengan dua nomor berbeda. Earlyanti (2010) menyatakan bahwa barang komplementer adalah barang yang melengkapi fungsi barang lainnya. Keberadaan nada sambung dapat melengkapi fitur yang disediakan telepon seluler sehingga nada sambung dan ponsel adalah pasangan barang komplementer. Hubungan antara nada sambung dan ponsel sebagai barang komplementer menyatakan bahwa keberadaan satu barang saja dari keduanya tidak akan membuahkan manfaat yang sebenarnya diinginkan konsumen. Keberadaan ponsel yang lebih banyak memungkinkan bertambah pula nada sambung yang diaktifkan seorang konsumen. Oksman dan Rautianinen (2001), diacu dalam Torlak, Spillan, \& Harcar (2011) menyatakan bahwa diantara kebanyakan remaja, penggunaan telepon seluler menjadi mekanisme penting untuk menghubungkannya dengan keluarga dan teman.

Kotler dan Armstrong (2008) melakukan penggolongan sumber informasi yang bisa diperoleh konsumen. Sumber-sumber itu meliputi sumber pribadi (keluarga, teman, tetangga), sumber komersial (iklan, wiraniaga, situs web, penyalur, kemasan, tampilan), sumber publik (media massa, organisasi pemeringkat konsumen, pencarian internet) dan sumber pengalaman (penanganan, pemeriksaan, pemakaian produk). Kotler dan Armstrong (2008) juga menyatakan bahwa pada umumnya, konsumen menerima informasi tentang sebuah produk dari sumber komersial, meski sumber pribadi dinilai paling efektif. Hasil penelitian memperlihatkan bahwa sumber publik (televisi, surat kabar, dan radio) ada di urutan pertama sebagai sumber informasi mahasiswa tentang nada sambung. Sumber informasi pribadi paling sedikit dipilih mahasiswa sebagai sumber informasi tentang nada sambung.

Solomon (1992) menyatakan bahwa mahasiswa mulai kesulitan mengakses televisi. Mahasiswa juga dinilai kurang memiliki akses yang baik menuju surat kabar. Solomon (1992) juga menyatakan bahwa strategi terbaik untuk mencapai konsumen mahasiswa adalah dengan menggunakan produk personal yang dekat dengan kesehariannya serta melakukan pengenalan produk di pusat informasi mahasiswa dan asrama. Meski demikian, Solomon (1992) menyatakan bahwa komunikasi verbal (word of mouth communication) tetap menjadi media penyebaran informasi yang baik bagi konsumen mahasiswa. Paparan Solomon (1992) di atas bertentangan dengan hasil penelitian. Hal itu diduga terjadi karena akses ke sumber publik (televisi) di asrama tidak sulit. Televisi selalu tersedia di setiap lobi asrama TPB IPB, sehingga mudah disaksikan mahasiswa. Schiffman dan Kanuk (1994) menyatakan bahwa pemaparan informasi di televisi yang kaya dengan petunjuk simbol visual dan durasi yang pendek dapat membentuk loyalitas terhadap merek.

Sebagian besar mahasiswa (86,5\%) mengaktifkan musik pop sebagai nada sambung mereka. Musik pop adalah jenis musik yang mudah ditemui dan biasanya tema asmara menjadi topik sentral. Topik ini menurut Solomon (1992) memang digemari konsumen remaja.

Selain penggunaan nada sambung, berbagai fitur ponsel juga memerlukan dana aktivasi agar bisa digunakan. Fitur lain tersebut adalah layanan SMS, panggilan telepon, dan internet. Lebih dari tiga perempat mahasiswa memilih nada sambung sebagai prioritas terakhir dalam pengalokasian dana untuk ponselnya. Hal itu menunjukkan bahwa nada sambung bukan aspek prioritas dalam daftar pengeluaran mahasiswa. Posisi pertama fitur ponsel yang diutamakan lebih dari separuh $(52,8 \%)$ mahasiswa adalah Short Message Service (SMS). Menurut Solomon (1992), konsumen mahasiswa selalu memperhitungkan pengeluarannya untuk keperluan pribadi. Oleh 

karena itu SMS adalah fitur yang didahulukan oleh mahasiswa sebab lebih dekat dengan keperluan pribadi mahasiswa.

Temuan bahwa SMS menjadi layanan utama dalam penggunaan sebuah telepon seluler juga senada dengan hasil penelitian yang dipaparkan Torlak, Spillan, \& Harcar (2011). Menurutnya, penggunaan ponsel sudah sedemikian populer di kalangan remaja. Penelitian cross-cultural mengungkap ketertarikan dan penggunaan ponsel yang sama oleh remaja dari beberapa negara berbeda. Saat berpikir tentang bagaimana remaja berinteraksi melalui telepon selulernya, interaksi sosial dengan temannya adalah hal yang utama. Dalam sebuah penelitian di Universitas Yunani (Greek University) yang melibatkan 416 mahasiswa peserta survei penggunaan telepon seluler, terungkap hasil yang mengindikasikan bahwa kebanyakan para mahasiswa menggunakan ponsel untuk tujuan panggilan telepon dan SMS. Sementara itu dalam studi lain di Norwegia dengan topik yang sama, peneliti menemukan bahwa 99,4 persen konsumen wanita paling banyak menggunakan ponselnya untuk fungsi SMS, sementara persentase mahasiswa pria sebesar 97,5 persen.

Kotler dan Armstrong (2008) menyatakan bahwa perilaku seseorang dipengaruhi oleh banyaknya kelompok kecil. Kelompok yang mempunyai pengaruh langsung dan menjadi tempat seseorang menjadi anggotanya disebut kelompok keanggotaan. Kelompok yang sering langsung membentuk sikap dan bertindak sebagai referensi langsung seorang konsumen disebut kelompok referensi. Kelompok referensi ini menurut Sumarwan (2004) disebut kelompok acuan. Kelompok yang terpengaruh oleh berbagai hal terkait kelompok acuan disebut kelompok asosiasi. Kotler dan Armstrong (2008) menambahkan bahwa konsumen sering dipengaruhi oleh kelompok referensi yang tidak dimasukinya sebagai anggota. Namun menurut Solomon (1992), konsumen yang ada di usia remaja akan mencari referensi bersikap dari teman sebayanya dan iklan agar terlihat dan bersikap dengan "baik". Schiffman dan Kanuk (2004) memperkuat pernyataan itu dengan menyatakan bahwa opini dan preferensi teman adalah sumber pengaruh yang penting dalam menentukan produk yang akan dipilih. Solomon (1992) juga menyatakan bahwa remaja sering kali terpangaruh oleh keputusan orang tuanya.

Hasil penelitian menyatakan kebalikan dari kedua informasi itu. Mahasiswa justru menjadikan kelompok yang ia tempati sebagai kelompok acuannya. Mahasiswa juga tidak menjadikan keluarga sebagai kelompok acuan seperti yang dinyatakan Solomon (1992), melainkan temannya. Hal ini terjadi karena mahasiswa adalah remaja yang berada di tingkat akhir fase transisi, sehingga sudah masuk ke fase dewasa awal, karenanya pengaruh orang tua sebagai acuan pembelian tidak lagi berpengaruh besar. Menurut hasil penelitian, diperoleh informasi bahwa kebanyakan mahasiswa $(39,5 \%)$ menjadikan temannya sebagai kelompok acuan yang mempengaruhi konsumsi nada sambung.

Menurut Sumarwan (2004), pengetahuan konsumen adalah semua informasi yang dimiliki konsumen mengenai berbagai macam produk dan jasa, serta pengetahuan lainnya yang terkait dengan produk dan jasa tersebut dan informasi yang berhubungan dengan fungsinya sebagai konsumen. Mowen dan Minor (1995) sebagaimana dikutip Sumarwan (2004) melakukan klasifikasi pengetahuan konsumen menjadi tiga jenis, yaitu pengetahuan objektif, pengetahuan subjektif dan informasi mengenai pengetahuan lainnya. Pengetahuan objektif adalah informasi yang benar mengenai kelas produk yang disimpan dalam memori jangka panjang konsumen. Pengetahuan objektif inilah yang diukur dengan 16 pertanyaan. Sebanyak lebih dari separuh mahasiswa $(55,6 \%)$ memiliki pengetahuan tentang nada sambung yang tinggi. Tidak ada mahasiswa yang memiliki tingkat pengetahuan rendah. Keterjangkauan mahasiswa terhadap sumber informasi adalah salah satu faktor yang diduga berkontribusi dalam tingginya tingkat pengetahuan. Solomon (1992) menyatakan bahwa komunikasi verbal (word of mouth communication) menjadi media penyebaran informasi yang baik bagi konsumen mahasiswa. Kedekatan dengan teman hingga menjadi kelompok acuan juga merupakan faktor lain yang diduga mempengaruhi tingginya pengetahuan mahasiswa, karena peluang terjadinya pertukaran informasi secara verbal lebih besar.

Sumarwan (2004) menyatakan bahwa konsumen seringkali memutuskan pembelian suatu produk berdasarkan persepsinya terhadap produk tersebut. Solomon (2002) menyatakan bahwa persepsi adalah proses yang dilalui saat sebuah sensasi seperti tampilan, suara, dan bau dipilih, diatur serta diterjemahkan. Timbulnya persepsi dimulai dari pemaparan stimulus yang kemudian diterima konsumen. Berdasarkan hasil penelitian, lebih dari separuh mahasiswa $(55,6 \%)$ menyatakan kurang setuju dengan keberadaan nada sambung. 

Sutisna (2001) menyatakan bahwa konsumen mengembangkan inferensi atau kesimpulan mengenai suatu produk. Hal itu disebut dengan inferensi perseptual. Inferensi itu merupakan kepercayaan mengenai suatu objek dari asosiasi masa lalu. Sutisna (2001) juga menggolongkan inferensi ke dalam tiga tipe, yaitu inferensi yang didasarkan pada evaluasi (evaluation based), evaluasi yang didasarkan pada kesamaan (similarity based) dan inferensi yang didasarkan pada korelasional.

Inferensi yang didasarkan pada evaluasi yaitu penilaian yang menimbulkan evaluasi positif atau negatif yang konsisten terhadap suatu merek. Artinya, jika pada awalnya konsumen sudah memperoleh informasi bahwa sebuah produk berkualitas baik, maka ketika konsumen itu membeli produk yang dikabarkan berkualitas baik dan penilaian baik itu disetujui, maka telah terjadi inferensi positif secara konsisten. Inferensi yang didasarkan pada kesamaan yaitu kepercayaan atas suatu objek yang didasarkan pada kesamaan dengan objek lain. Konsumen mengembangkan inferensi terhadap merek yang tidak diketahuinya dengan menghubungkan dengan merek lain yang dikenalnya. Inferensi korelasional didasarkan pada asosiasi dari hal umum kepada hal yang spesifik. Misalnya, konsumen percaya bahwa harga yang lebih mahal menunjukkan kualitas yang lebih baik.

Berdasarkan tiga klasifikasi inferensi perseptual tersebut, pembentukan persepsi mahasiswa terjadi melalui inferensi yang didasarkan pada evaluasi. Persepsi kurang setuju yang terbentuk terjadi sebagai lanjutan dari penerimaan stimulus tentang produk dari berbagai media.

Berdasarkan klasifikasi perilaku pembelian menurut Kotler dan Armstrong (2008), perilaku pembelian konsumen nada sambung tergolong perilaku pembelian mencari keragaman. Jenis ini ditandai dengan rendahnya keterlibatan konsumen untuk memperoleh informasi tentang produk yang sama dengan merek berbeda, padahal merek untuk produk ini tidak berjumlah sedikit.

Hasil penelitian juga menunjukkan bahwa sebagian besar mahasiswa memilki perilaku pembelian dalam kategori "pernah" dengan skor rata-rata sebesar 48,4. Informasi tentang perilaku pembelian mahasiswa bisa digunakan untuk memprediksi perilaku pembelian berikutnya, sebagaimana yang Sutisna (2001) nyatakan bahwa penentu akhir tindakan konsumen di masa yang akan datang adalah pengalaman dengan penggunaan produk.

Kotler dan Armstrong (2008) melakukan empat klasifikasi jenis perilaku keputusan pembelian yang dilakukan konsumen. Jenis perilaku keputusan pembelian yang pertama adalah perilaku pembelian kompleks. Jenis perilaku pembelian ini menuntut keterlibatan konsumen yang tinggi dan banyak perbedaan merek produk yang akan dibeli. Jenis kedua adalah perilaku pembelian pengurangan disonansi. Perilaku pembelian ini juga perlu dilakukan dengan keterlibatan tinggi agar informasi tentang sebuah produk didapat secara utuh. Namun dalam perilaku pembelian ini, keragaman merek produk yang dipilih tidak tinggi. Perilaku pembelian selanjutnya adalah perilaku pembelian kebiasaan yang tidak menuntut keterlibatan tinggi dan keragaman merek yang juga tidak tinggi. Jenis perilaku pembelian terakhir adalah perilaku pembelian mencari keragaman. Dalam jenis perilaku pembelian ini, banyak terdapat perbedaan merek, namun keterlibatan untuk memilih produk mana yang akan dikonsumsi tidak bernilai tinggi.

Menurut Earlyanti (2008), faktor-faktor yang mempengaruhi pola konsumsi adalah tingkat pendidikan konsumen, selera konsumen yang ditunjukkan dengan persepsi, harga barang, tingkat pendapatan, jumlah anggota keluarga dan kondisi lingkungan yang ditempati konsumen. Berdasarkan uji regresi linear berganda, dapat disimpulkan bahwa variabel bebas yang berpengaruh nyata terhadap perilaku pembelian nada sambung oleh mahasiswa TPB IPB adalah persepsi konsumen. Persepsi konsumen juga berbanding lurus dengan variabel terikat (perilaku pembelian). Perolehan itu senada dengan paparan Earlyanti (2008), meskipun kelima variabel independen lain yang diteliti (pengetahuan, usia, jenis kelamin, jumlah anggota keluarga dan uang saku) tidak berpengaruh nyata terhadap perilaku pembelian nada sambung pada mahasiswa. Pernyataan Verbeke (2002), diacu dalam Gellynck et al. (2009) juga sesuai dengan hasil penelitian yang menyatakan bahwa persepsi konsumen menentukan preferensi, sikap, pilihan serta perilaku pembelian konsumen itu.

\section{SIMPULAN DAN SARAN}

Lebih dari separuh mahasiswa memiliki pengetahuan tentang nada sambung yang tinggi dan memiliki persepsi kurang setuju terhadap keberadaan nada sambung. Tingkat 

persepsi mempengaruhi perilaku pembelian nada sambung. Sebagian besar mahasiswa memiliki perilaku pembelian dalam kategori pernah. Berdasarkan uji regresi linier berganda, persepsi konsumen berpengaruh positif nyata $(p<0,01)$ terhadap perilaku pembelian nada sambung konsumen.

Hasil penelitian menunjukkan bahwa kebanyakan mahasiswa menjadikan temannya sebagai kelompok acuan. Oleh karenanya, penyampaian pesan dalam iklan sebaiknya dikemas dalam suasana pertemanan serta tema kekompakan dan kebersamaan dengan teman. Selain itu positioning produk juga perlu ditingkatkan agar konsumen merasakan nilai tambah baru dalam penggunaan nada sambung. Cara yang bisa ditempuh untuk meningkatkan positioning produk adalah dengan melakukan beberapa inovasi, misalnya lagu baru seorang musisi hanya bisa didapat melalui nada sambung, tokoh tertentu menggunakan nada sambung, dan lain-lain.

\section{DAFTAR PUSTAKA}

Cobb, N. J. (2001). Adolescene: Continuity, Change and Diversity. California: Mayfield Publishing Company.

Earlyanti, N. I. (2008). Konsumsi [internet].[Diacu 2011 Juli 11]. Diambil dari: http://www.e-dukasi.net/index.php? mod=script\&cmd=Bahan\%20Belajar/ Materi\%20Pokok/view\&id=216\&uniq =239 3.

Engel, J. F., Blackwell, R. D., \& Miniard, P. W. (1995). Perilaku Konsumen Jilid 2. Jakarta: Binarupa Aksara.

Gellynck, X., Kuhne, B., Van Bockstaele, F., \& Van de Walle, D., Dewettinck, K. Consumer perception of bread quality. Appetite, 53, 16-23

Hawkins, D. I., Best, R. J., \& Coney, K. A. (2001). Consumer Behavior: Building
Marketing Strategy: $8^{\text {th }}$ Edition. Boston: Irwin-McGraw-Hill.

Kotler, P., \& Armstrong, G. (2006).PrinsipPrinsip Pemasaran, Edisi Ke-12. Jakarta: Penerbit Erlangga.

Mowen, J. C., \& Minor, M. (1998). Consumer Behavior. $4^{\text {th }}$ Edition. New Jersey: Prantice Hall.

Peter, J. P., \& Olson, J. C. (1996). Consumer Behavior and Marketing Strategy Fourth Edition. United States of America: Times Mirror Higher Education Group.

Putranto, W. (2009). Rolling Stone Music Biz. Yogyakarta: B-First

Putranto, W. (2010, Maret). Era Baru Musik Digital.Rolling Stone. Edisi 59: 23

Schiffman, L. G., \& Kanuk, L. L. (1994). Consumer Behaviour Fifth Edition. New Jersey: Prentice-Hall, Inc.

Solomon, M. R. (1992). Consumer Behaviour: Buying, Having and Being. Massachusetts: Allyn and Bacon.

Sumarwan, U. (2004). Perilaku Konsumen: Teori dan Penerapannya dalam Pemasaran. Bogor: PT Ghalia Indonesia.

Sutisna. (2001). Perilaku Konsumen dan Komunikasi Pemasaran. Bandung: PT Remaja Rosdakarya.

Torlak, O., Spillan, J. E., \& Harcar T. Young Consumer's Cell Phone Usage in Developing Market: The Case of Turkish Youth Market. Journal of Marketing Development and Competitiveness, 5 , 47-67.

[YLKI] Yayasan Lembaga Konsumen Indonesia. (2011). Pencurian Pulsa Dominasi Pengaduan Konsumen ke YLKI. Diambil dari: http://www.ylki. or.id/pencurian-pulsa-dominasi-pengaduan-konsumen-ke-ylki.html. 